\title{
A note on productive performance of feedlot heifer-calves fed according to two daily feeding frequencies
}

\author{
C. Machado, H. Matoso and N. Auza
}

National University, Buenos Aires,

Faculty of Veterinary Sciences

Pinto 399. Tandil (7000)(UNCPBA), Argentina

(Received 19 September 1996; accepted 6 February 1997)

\begin{abstract}
One hundred Aberdeen $A$ ngus and $\Lambda \mathrm{A} x$ llereford heifer-calves $(158 \pm 9.6 \mathrm{~kg}$ ) were penned and randomly allocated to two feeding frequencies: T2 - twice daily $(8: 00$ and $17: 00 \mathrm{~h})$ and $\mathrm{T} 4$ - four times daily $(8: 00,11: 00,14: 00$ and 17:00 h). The animals were fed for 69 days a commercial pelleted concentrate and hay ration for 69 days until slaughter. Hay and concentrate intake were recorded daily. Calves were fasted ( $15 \mathrm{~h}$ period) and weighed at 15 -day intervals. Dressing percentage, $11^{\circ}$ rib surface and fat-bonc-muscle relation were estimated in the carcasses. Feeding frequency had no effect $(\mathbf{P}>0.05)$ on the productive parameters evaluated.
\end{abstract}

KEY WORDS: feeding frequency, feedlot, heifer-calf, carcass

\section{INTRODUCTION}

$\Lambda$ new market has emerged in Argentina for veal meat produced from feedlot heifer-calves. These animals are slaughtered prior to reaching $250 \mathrm{~kg}$ live weight (LW). In intensive systems such as feedlots, feed costs are frequently the most important profit factor and can reach $70-80 \%$ of the total costs of a heifer-calf feedlot (Machado et al., 1995). For this reason, it is necessary to optimize the potential for growth and food conversion efficiency of animals. Concentrates are usually the main component of the diets in feedlot systems. Feeding frequency 
has been mentioned as a way to improve nutritional efficiency (Sniffen and Robinson, 1984). Gibson (1981) reviewed information about effects of feeding frequency on animal performance and found that an increase of 2.2 and $21.2 \%$ in of daily liveweight gain, respectively, for feeding twice and four times daily, compared to once a day feeding. Concentrate feeding frequency has been studied at different times during the day (Gibson 1981; Mc Lachlan et al., 1994; Robinson and McNiven, 1994; Goonewardene et al., 1995) and at different frequencies between days (Godfrey et al., 1993; Beauty et al., 1994). The short-term feedlot process necessary for finishing heifer-calves requires a rapid adaptation to concentrates, so as to achieve a high average daily gain (ADG) and feed conversion efficiency (FCE). This study was designed to establish the productive responses of heifer-calves fed twice or four times a day.

\section{MATERIAL AND METHODS}

One hundred Aberdeen Angus (AA) and AA x Hereford heifer-calves (average LW $158 \mathrm{~kg} \pm 9.6 \mathrm{SD}$ ) were randomly allocated to eight pens (12-13 animals per pen) with four pens being assigned to each of two treatments. The treatments consisted of feeding the same amount of feed on two times (T2) or four times (T4) per day. Animals in T2 were fed at 8:00 and 17:00, and T4 at 8:00, 11:00, 14:00 and 17:00 h. Diets were conformed for hay and concentrate (maize grain, brewer grain and sunflower expeller). A 14-day adjustment period was necessary to achieve the target intake of concentrate $(85 \%$ of the whole dry matter intake per day). Diets were periodically adjusted to avoid feed intake restriction. Three types of hay were used throughout the trial; the chemical composition of the feeds is shown in Table 1. Diets were designed to satisfy a daily gain weight of $1.2 \mathrm{~kg} \mathrm{~d}^{-1}(\mathrm{NRC}, 1980)$. Water was provided ad libitum.

Hay and concentrate intake were estimated daily on a group basis with the feed not eaten from the previous day. Animals were weighed after a $15 \mathrm{~h}$ fasting

TABLE 1

Chemical composition of feeds

\begin{tabular}{lcccc}
\hline \multirow{2}{*}{ Indices } & \multicolumn{3}{c}{ Hay } & Concentrates \\
\cline { 2 - 4 } & red clover & ryegrass & lucerne & \\
\hline Dry matter, \% & 86.4 & 79.3 & 88.5 & 87.4 \\
NDF, \% & 57.5 & 77.3 & 63.5 & - \\
DMD, \% & 58.1 & 46.9 & 50.9 & 77.5 \\
CP, \% & 12.5 & 6.6 & 14.3 & 16.7 \\
ME, Mcal/kg DM & 2.10 & 1.69 & 1.84 & 2.80 \\
\hline
\end{tabular}


period on days $0,14,28,41,55$ and 69 of the trial. Average daily gain (ADG) was calculated as gain over time; feed intake (FI) and feed conversion efficiency (FCE) were determined on a pen basis. Since all the animals did not reach slaughter weight at the same time, only 10 animals per treatment were used for carcass evaluation.

The S.A.S ${ }^{\mathbb{B}}$ program (1989) was used for statistical analysis. The treatments nested in pen were used as the error to test for differences between treatments. The live weight at the start of the trial was included as a covariate. Treatment differences for FI and FCE were analyzed on a pen basis using a one-way analysis of variance.

\section{RESULTS AND DISCUSSION}

The effect of feeding frequency on productive performance is shown in Table 2 . No significant differences were detected in any of the evaluated parameters. These results are similar to those reported by Stanton et al. (1990) and Goonewardene et al. (1995). From a summary made by Gibson (1981) of several trials, it was possible to calculate an improvement of $18.6 \%$ of LWG for multiple daily feeding frequency, assuming $1 \mathrm{~kg} / \mathrm{d} \mathrm{LWG}$ with one meal per day. The improvement of the present study was only of $4.6 \%$, and LWG and FCE of this study were $1.11 \mathrm{~kg} /$ day and $4.83 \mathrm{~kg} \mathrm{~kg} \mathrm{LW}^{-1}$, respectively. When the performance of crossbred Frisian $x$ Charolais heifer-calves fed with a 2:1 of concentrate: hay

TABLE 2

The effect of feeding frequency on weight, average daily gain, feed intake, feed efficiency and carcass quality

\begin{tabular}{lccc}
\hline \multirow{2}{*}{ Indices } & \multicolumn{2}{c}{ Feeding frequency } & \multirow{2}{*}{ SEM } \\
\cline { 2 - 3 } & $\mathrm{T} 2$ & $\mathrm{~T} 4$ & \\
\hline Initial weight, $\mathrm{kg}$ & 155.9 & 160.0 & 2.6 \\
Final weight, $\mathrm{kg}$ & 230.3 & 238.0 & 4.3 \\
Average daily gain, $\mathrm{kg} / \mathrm{d}^{-1}$ & 1.09 & 1.14 & 0.03 \\
Average feed intake, $\mathrm{kg} / \mathrm{d}^{-1}$ & 5.31 & 5.38 & 0.05 \\
Concentrate in the diet, \% & 68.5 & 65.2 & 2.20 \\
Convertion feed efficiency, $\mathrm{kg} / \mathrm{kg} \mathrm{LW}^{-1}$ & 4.91 & 4.75 & 0.14 \\
Dressing percentage, \% & 53.9 & 54.1 & 0.50 \\
Muscle, \% & 58.6 & 59.1 & 0.45 \\
Fat, \% & 18.7 & 18.1 & 0.53 \\
Bone, \% & 22.7 & 21.8 & 0.09 \\
$1^{10}$ rib surface, $\mathrm{cm}^{2}$ & 48.0 & 48.6 & 0.47 \\
\hline
\end{tabular}

SEM: pooled standard error of the mean 
ratio was evaluated, $1.0 \mathrm{~kg} /$ day of $\mathrm{ADLW}$ and $5.39 \mathrm{FCE}$ were obtained (Burgstaller et al., 1984). Since these authors slaughtered their animals at a higher weight than the present trial (from $157.3 \mathrm{~kg}$ at begining to $354.4 \mathrm{~kg}$ of final weight), the productive performance of our study was superior. The improved LWG as a result of increased feeding frequency has been partly attributed to improved dry matter intake (Coleman and Wyatt, 1982) and more uniform rumen conditions (Linn and Otterby, 1984, quoted by Goonewardene et al., 1995). However the response to increased feeding frequency is highly dependent on the characteristics of the diet, such as proportion of forage (Ruiz and Mowat, 1987) and feed quality (Bunting et al., 1987).

In relation to carcass evaluation, Augustini et al. (1993) slaughtered beef-cattle type heifer-calves of $200 \mathrm{~kg} \mathrm{LW}$, which had $66.1,9.2$ and $18.9 \%$ of muscle, fat and bone, respectively. In our trial a higher proportion of fat and bone than Augustini's study was found, probably associated with the different breeds and slaughter weights used. Based on our results, it is possible to conclude that no improvement was detected by increasing the feeding frequency of feedlot heifer-calves from twice to four times a day.

\section{REFERENCES}

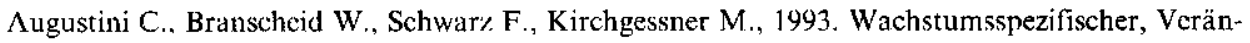
derung der Schlachtgewicht auf die grobgewebliche Zusammensetzung von Färsenschlachtkörpern. Fleischwirtschaft 73, 595-599

Bunting L., Howard M., Muntifeering R., Dawson K, Boling J., 1987. Effect of feeding frequency on forage fibre and nitrogen utilization in sheep. J. Anim. Sci. 64, 1170-1177

Beauty J., Cochran R., Lintzenich B., Vanzant E., Morrill J., Brandt R. Jr., Johnson D., 1994. Effect of frequency of supplementation and protein concentration in supplement on performance and digestion characteristics of beef cattle consuming low-quality forages. J. Anim. Sci. 72, 2475-2486

Burgstaller V., Ferst R., Alps II., 1984. 7.um Zusat\% von Milchsäurebakterien (Streptococcus faecium SF-68) im Milchaustauschfuttermittel für Mastkälber. Züchtungskunde 56,156-162

Coleman S., Wyatt R., 1982. Cottonseed meal or small grain forages as protein supplements fed at different inntervals. J. Anim. Sci. 55, 11-17

Godfrey S., Rowe J., Speijers E., Toon W., 1993. Lupins, barley plus Virginiamycin as supplements for shecp at different feeding intervals. Aust. J. Exp. Agric. 33, 135-140

Goonewardene L., 7oßell D., Engstrom D., 1995. Feeding frequency and its effect on feedlot performance in steers. Can. J. Anim. Sci. 75, 255-257

McLachlan B., Ehrlich W., Cowan R., Davison M., Silver B., Orr W., 1994. Fffect of level of concentrate fed once or twice daily on the milk production of cows grazing tropical pasture. Aust. J. Exp. Agric. 34, 301-306

Machado C., Ponssa E., Matoso D., 1995. Evaluación económica del engorde a corral de terneras. Parte I. Simulación a partir de un caso real. Rev. Argentina Prod. Animal. 15, (3-4), 1148-1150 
Robinson P., MeNiven M., 1994. Influence of flame roasting and feeding frequency of barley on performance of dairy cows. J. Dairy Sci. $77,3631-3643$

Ruiz $\Lambda$., Mowat D., 1987. Effect of feeding frequency on the utilization of high forage dicts by cattle. Can. J. Anim. Sci. 67, 1067-1074

SAS/STAT ${ }^{\text {wit, }}$ User's guide (1989). Version 6, 4th Edition, Vol. 2

Sniffen C., Robinson P., 1984. Nutritional strategy. Can. J. Anim. Sci. 64, 529-542

Stanton T., Schutz D., Averch S., 1990. Feeding time and finishing heifer performance. J. Anim. Sci. 68,191

\section{STRESZCZENIE}

Wyniki produkcyjne cieląt-jalówek żywionych z różną częstotliwością w ciągu dnia

Stu cielętom-jałówkom Aberdeen-Angus i mieszańcom AA x Hereford (158 $\pm 9,6 \mathrm{~kg})$, rozdziclonym losowo do kojców, podawano paszę 2 razy ( 8 i 17 godz.) lub 4 razy $(8,11,14$ i 17 godz.) dziennie. Zwierzęta żywiono przez 69 dni przemysłową granulowaną paszą treściwą i sianem aż do uboju. Pobranie paszy treściwej i siana oznaczano codziennic. Jałówki ważono co 15 dni po 15 godz. głodzenia. Oznaczono wydajność rzeźną, powierzchnię oka przy 11 żebrze oraz stosunck thuszczu : kości : mięsa w tuszy. Częstoliwość podawania paszy nie miała wpływu $(P>0,05)$ na badane wskaźniki produkcyjnc. 